\title{
Review Article \\ The Review on Properties of Aloe Vera in Healing of Cutaneous Wounds
}

\author{
Seyyed Abbas Hashemi, ${ }^{1}$ Seyyed Abdollah Madani, ${ }^{2}$ and Saied Abediankenari ${ }^{3}$ \\ ${ }^{1}$ Department of Otolaryngology, Head and Neck Surgery, Traditional and Complementary Medicine Research Center, \\ Mazandaran University of Medical Sciences, Sari, Iran \\ ${ }^{2}$ Traditional and Complementary Medicine Research Center, Mazandaran University of Medical Sciences, \\ Sari, Iran \\ ${ }^{3}$ Immunogenetic Research Center, Faculty of Medicine, Mazandaran University of Medical Sciences, \\ Sari, Iran \\ Correspondence should be addressed to Seyyed Abdollah Madani; abdollahmadani1356@gmail.com
}

Received 28 February 2015; Accepted 12 May 2015

Academic Editor: Goutam Ghosh Choudhury

Copyright (C) 2015 Seyyed Abbas Hashemi et al. This is an open access article distributed under the Creative Commons Attribution License, which permits unrestricted use, distribution, and reproduction in any medium, provided the original work is properly cited.

\begin{abstract}
Treatment of wounds is very important and was subject of different investigations. In this regard, natural substance plays crucial role as complementary medicine. Various studies reported that aloe vera has useful effects on wounds especially cutaneous wounds healing. Therefore in the current review, we examined the effect of aloe vera on cutaneous wound healing and concluded that although aloe vera improves the wound healing as well as other procedures both clinically and experimentally, more studies are still needed to approve the outcomes.
\end{abstract}

\section{Introduction}

The skin plays an important role in protection from the body internal environment and it is the largest organ in human's body so exertion of serious damage to this organ may cause several problems in its survival. Skin is composed of two layers of epidermis and dermis that are placed over the subcutaneous adipose. Epidermis mainly comprises keratinocyte layers in which some other types of cells have spread including melanocytes and Langerhans cells. Epidermis has been separated from dermis by the basal membrane. Dermis is composed of papillary and reticular cells that comprise extracellular matrix or the basal substance consisting of collagen, fibrous networks, elastin, and glycosaminoglycans [1]. Despite various modern skin cares and treatments using herbal products like aloe vera plays an important role in wound healing especially in complementary medicine. Therefore in this paper we examined the effect of aloe vera on cutaneous wound healing.

\section{Wound Healing, Classification, and Cell Signaling}

Burning emerges as tissue trauma that is defined by some factors such as heat, chemicals, electricity, sunlight, and/or nuclear radiation. Most of burning cases are caused by building fires, touching the boiled water, water steam, liquids, and flammable gases [2].

The burning caused by heat and accidents and the like is assumed as the foremost cause of mortality and disability in the victims [3]. Two million people received medical treatments caused by burning traumas every year. Most of the primary treatments including drug topical dosage are employed to prevent against penetration of infectious substances into the wound. Improvement in methods of wound therapy and recovery of tissue may enhance the quality of life in the patients with burning trauma and also it may probably contribute to reducing the medical costs [4]. Treatment of dermal wounds is a complicated process that is the result 
of common performance between the various tissues with several cellular colonies. The behavior of each type of effective cells has been characterized during proliferation, migration, matrix building and contraction, phases and growth factors, and the existing matrix signals in the wound place at present [5]. A series of usual events may occur to treat the injury after trauma. As a result of inflammatory response due to trauma, the cells behind the dermis start building collagen and this continues up to the end of building epithelium [6].

Following incidence of any type of trauma on skin of other body tissues, a series of cellular and molecular events occurs. Wound healing includes three phases of thrombosis and inflammation, proliferation and formation of new tissue, and tissue retrieval [9]. The paramount cellular signaling events and extracellular matrix activities in healing process are controlled by various types of growth factors including fibroblastic growth factors (FGFs), epidermal growth factors (EGFs), transforming growth factors (TGFs), and insulin-like growth factors (IGFs). The insulin-like growth factor includes some peptides, which are very similar to insulin in terms of structural sequence and they are called somatomedin-C due to stimulation for secretion of growth factor hormone. These compounds play their role through various paths of autocrine, paracrine, and endocrine [10].

The insulin-like growth factors (IGFs) are secreted by few numbers of dermis and epidermis cells in normal skin but during dermal trauma they are secreted by most of epidermal cells including macrophages and platelets. This family of growth factors stimulates mitogenic fibroblasts and they also intervene in angiogenesis trend [11].

Other studies have shown that IGFs along with other factors such as platelet-derived growth factors (PDGFs) play important role in process of wound healing so that they increase the thickness of dermis and epidermis. The rate of expression of IGF genes is low in epidermal basal layer, but this rate is significantly increased for one to three days after incidence of the wound $[12,13]$. It has been shown in other investigations that abnormal increase in IGF may raise the expression and production of pro-alpha-I chain gene from collagen type-I and pro-alpha-I of collagen type-III in wound fibroblasts and as a result it will prepare the grounds for increase in size of scar (wound trace) [8, 13-16] (Figure 1).

Principally, the wound is defined as a lesion and rupture on skin surface that is caused by physical or thermal traumas, which need medical therapy. Improvement and healing of wound in human or developed animals occur with a completely complex and advanced mechanism as a result of passing through several phases including inflammation, proliferation, healing, and reconstruction [17]. Initially, the created gap on place of wound is closed quickly and epithelium is created again on surface of wound and a new matrix is substituted promptly with the lost skin. Nonetheless, if the above-said scheduled events are disrupted for any reason, the healing trend of skin wound encounters problem, and wound healing speed is affected by them. A lot of factors affect speed and quality of wound healing trend out of which one can refer to size of wound, blood storage on place, the existing external objects and microorganisms, age, health status, and nutrition state of patient $[7,18-20]$ (Table 1).
The other classification of wounds is based on quality and period of healing trend where accordingly the wounds can be divided into two groups of acute and chronic wounds. The acute wounds are called a group of injuries, which is usually surficial and they are healed completely within period of 8-12 weeks. The chronic wounds are said to be a group of wounds, which is slowly healed and period of their healing exceeds 12 weeks. These wounds are often recurring and continue. These wounds are created under conditions of special diseases like malignancies and chronic infections and/or under certain physiological conditions such as wounds in diabetic patients that occur in their body. The foot wounds with traumatic and ischemic and venal origin are considered as this group of wounds [21-24].

\section{History}

With respect to advancement of modern techniques for wound healing on the one hand and tendency to use healing property of medicinal herbs as a complementary medicine on the other hand during recent decades, this trend has caused creating of serious discussion and challenges about therapy of patients with dermal wounds and skin healing among the dermatologist physicians and specialists in plastic surgery $[25,26]$.

\section{Pharmacognostical Characteristics}

Aloe vera is a plant that belongs to Liliaceae family that grows easily in hot and arid regions. The existing mucilage tissue at the center of leaves in this plant that is also so-called aloe gel is used for various cosmetics and medical applications. The peripheral leaf cells in this plant produce bitter and yellowcolor latex that is called aloes. Aloe vera is one of the plants, which can be noticed in this regard [27].

Aloe vera or yellow aloe is the herbaceous and perennial plant with thick, succulent, and long leaves. The margin of its leaves is a little curled with thistle. Its flowers are placed in beautiful clustering form at the end of florescent stem axis with green to yellow color. Aloe vera is endemic to African regions and it is also called desert lily (Hesperocallis) [28].

The Egyptians used aloe vera plant for treatment of wounds, burnings, and infections for the first time. After them, Greeks, Spanish, and African peoples used aloe vera plant by various techniques for several purposes. According to classic medicine in Iran, aloe vera has hot and dry humor and its extract is used for medicinal purpose $[29,30]$.

\section{Chemical Constituents}

Aloe vera plant is composed of anthracene hydroxyl derivatives including aloins $\mathrm{A}$ and $\mathrm{B}_{2}$ with total $25-40 \%$ of chromone compounds and derivatives such as aloe resins A, B2, and C. The other important compounds in aloe vera plant include several sugars such as glucose, mannose, and cellulose and various enzymes like oxidase, amylase, and catalase and also vitamins consisting of $\mathrm{B}_{1}, \mathrm{~B}_{2}, \mathrm{~B}_{6}, \mathrm{C}, \mathrm{E}$, and folic acid, and minerals like calcium, sodium, magnesium, zinc, copper, and chrome [31]. 
TABLE 1: Growth factors in wound healing [7].

\begin{tabular}{|c|c|c|}
\hline Growth factor & Source & Wound healing related functions \\
\hline PDGF & Platelets, macrophages, endothelial cells, injured cells & Chemotaxis, fibroblast proliferation, collagenase production \\
\hline TGF- $\beta$ & $\begin{array}{l}\text { Macrophages, platelets, neutrophils, lymphocytes, } \\
\text { fibroblasts, epithelial and endothelial cells, injured cells }\end{array}$ & Chemotaxis, fibroblast proliferation, collagen metabolism \\
\hline EGF & Macrophages, platelets, plasma, epithelial cells & Epithelial cells proliferation, granulation tissue formation \\
\hline TGF- $\alpha$ & $\begin{array}{l}\text { Activated macrophages, platelets, injured cells, } \\
\text { epithelial cells }\end{array}$ & Epithelial cells proliferation, granulation tissue formation \\
\hline KGF & Fibroblasts & Endothelial cells proliferation \\
\hline IL-1 & Macrophages & Fibroblast proliferation \\
\hline FGF & Macrophages, fibroblasts, pituitary, endothelial cells & $\begin{array}{l}\text { Fibroblast proliferation, matrix deposition, wound } \\
\text { contraction angiogenesis }\end{array}$ \\
\hline TNF- $\alpha$ & Macrophages, T lymphocytes & Fibroblast proliferation \\
\hline IGF-1 & Plasma, liver, fibroblasts & $\begin{array}{l}\text { Synthesis of sulfated proteoglycans and collagen, fibroblast } \\
\text { proliferation }\end{array}$ \\
\hline IFNs & Lymphocyte, fibroblasts & Inhibition of fibroblast proliferation and collagen synthesis \\
\hline
\end{tabular}

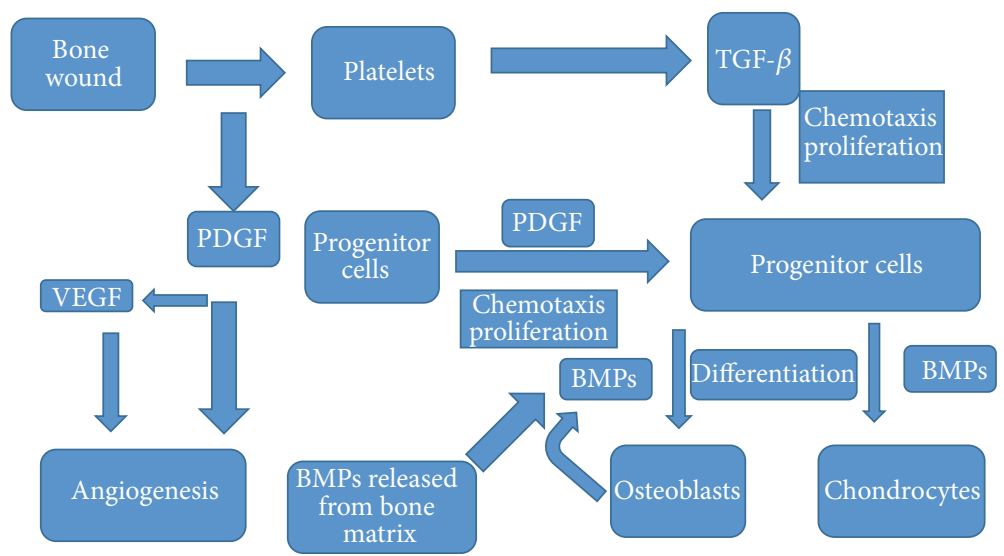

FIGURE 1: Signaling in wound healing: platelet-derived growth factor (PDGF), vascular endothelial growth factor (VEGF), and transforming growth factor-beta (TGF- $\beta)[8]$.

\section{Therapeutic and Pharmacological Effects}

One could refer to some of pharmacological activities attributed to aloe vera plant including anti-inflammatory, antiarthritis, antibacterial and antifungal, and hypoglycemic effects. Due to antibacterial and antifungal properties of aloe vera, this plant prevents against creation of dandruff on head. The aloe vera plant is also helpful for control of fungal infections such alopecia disease [32]. Of other effects, which have been ascribed to aloe vera fresh gel, one can imply its healing effects in wounds and skin surficial traumas. Similarly, reducing pain on place of trauma is seen following taking this drug [33]. The humid effects of aloe vera have been demonstrated in topical products of this plant as well [34]. The effects of aloe gel on skin improve the dermal intake of drugs as well. In a study that was carried out on effect of rising intake by aloe vera on drugs of caffeine, colchicines, mefenamic acid, oxybutynin, and kinin, this effect of skin rising intake was observed, which may be due to increase in water content (stratum corneum) [35].
Aloe vera (or yellow aloe) plant looks like cactus and a succulent and watery plant, whose leaves include mucilage tissue (gel). This mucilage consists of some glycoproteins, which prevent against inflation and pain and accelerate their improvement trend. Likewise, it comprises polysaccharides, which stimulate skin growth and healing. The mucilage of this plant can be used for treatment of internal and external wounds $[36,37]$.

\section{Healing Mechanism}

Its healing property is related to a compound that is called glucomannan, which is enriched with polysaccharides like mannose. The glucomannan affects fibroblast growth factor and stimulates the activity and proliferation of these cells and in turn improves collagen production and secretion. The mucilage of aloe vera not only increases amount of collagen on wound site, but also increases transversal connections among these bands rather than creation of change in collagen structure and as a result accelerates wound improvement [38]. 
Using medicinal herbs has been noticed in therapy of types of wound from the very beginning. Due to reduced financial load and its medical effects, these plants are noticed by the people. Several plants are used traditionally in treatment of many skin wounds and burnings in various points of the world [39]; among them one can refer to plants of jujube, mountain germander, olibanum, and also portulaca, whose effect has been proved during trend of healing of burning wounds in rats [40-42]. Inter alia, aloe vera is widely used as one of the plants with a very long history of healing of skin wounds and burnings.

It has been characterized that oral dosage of aloe vera mucilage by the rat with diabetes type-II has accelerated the trend of healing of skin wounds in these animals so that the results indicate that aloe vera treatment has accelerated the rising rate of expression in gene of vascular endothelial growth factor (VEGF) and TGF $\beta-1$ in the area of wound in skin of rats. In this case, TGF- $\beta 1$ has stimulated fibroblasts to better reconstruct the extracellular matrix at wound place more than ever [43].

After creation of skin wound, the inflammatory responses and collagen rising production start by the cells in dermal area which is followed by rearrangement of epithelial tissue. This is a physiological process and many factors may intervene in it including growth factors and cytokines in quality of its trend. The wound healing is aimed at its therapy at the minimum possible time and with least amount of pain and ache and scar for the patient [44-46].

\section{The Role of Growth Factors}

The growth factors are proteins with heavy molecular weight that is produced by most of cells and as it secretes they start autocrine and paracrine autocascading mechanisms in various cellular processes. Among several effective growth factors in trend of wound healing one can imply transforming growth factors TGF- $\beta$. Following trauma in tissues, TGF- $\beta$ is released from wound place by platelets degranulation [47].

In the study done by Roberts et al., upon occurrence of dermal trauma, TGF- $\beta 1$ appears with platelet origin on the wound point and caused progress in wound healing trend [48].

TGF- $\beta 1$ has increased mitosis power in fibroblasts of human's skin [49].

TGF- $\beta$ causes increase in angiogenesis trend of various tissues by improving the expression of angiogenetic factors like VEGF in epithelial and fibroblast cells [50, 51]. TGF$\beta$ stimulates angiogenesis, proliferation of fibroblasts, differentiation of myofibroblasts, and formation of extracellular matrix [52].

TGF- $\beta 1$ regulates and increases genetic expression of 2FGF on site of skin wound [53].

In this course, other investigations have shown as well that $\beta$-sitosterol as one of the elements of aloe vera mucilage has increased angiogenesis and better healing of traumatic tissues by increase in rate of genetic expression of VEGF and its receptor on place of wound [54]. Also, experiments in vitro regarding stimulation of macrophages in the damaged tissues have shown that the existing mannose sugar in aloe vera compound stimulates these cells for producing cytokines and progress in some phases of wound healing after connection to the given receptor locating on surface of skin macrophages. In this sense, Trade Name of Acemenan has been assumed as a therapeutic compound for a group of polysaccharides enriched with mannose in aloe vera mucilage [55].

Atiba et al. (2011) showed that oral dosage of aloe vera mucilage might increase production of bFGF and TGF- $\beta 1$ in place of wound on skin of rats, which had been exposed under a type of radiation [43]. Similarly, in another study (2010) it was identified that dermal dosage of aloe vera mucilage in wound place of rats has accelerated the healing as well as thrombosis and contraction of the wound point. It was known in this survey that dermal treatment with aloe vera has increased angiogenesis as well as granulated tissue and also better arrangement of collagen on wound site [56]. Topical dosage of aloe vera mucilage had led to healing of the shear wound in desert rat and rabbit [57].

\section{The Role of Vitamins and Others}

Aloe vera mucilage includes some compounds like vitamin $\mathrm{E}$ and vitamin $\mathrm{C}$ and some of amino acids, which can play important role in acceleration of wound healing trend in such a way that the experiments have indicated that vitamin $C$ with increase in producing collagen and prevention from synthesis of these strands as well as vitamin E as a strong antioxidant enters in wound healing trend [58]. With antimicrobial and anti-inflammatory effects, aloe vera mucilage also causes the progress in wound healing trend [59]. The aloe vera mucilage possesses antioxidant enzymatic systems like glutathione peroxidase and superoxide dismutase, which accelerate wound healing trend by neutralization of effect of the free radicals produced on wound site and with their anti-inflammatory property [60].

A study by Daburkar et al. showed that use of aloe vera gel ethanolic extract attenuated the diabetic foot wound in rats [61]. Another article revealed that aloe vera could be a treatment of choice for burn injuries [62]. Oryan and coworkers [63] proved evidences that topical application of aloe vera would improve the biochemical, morphological, and biomechanical features of the healing cutaneous wounds in rats. A clinical trial investigation reported that aloe vera and Calendula ointment improve the speed of episiotomy wound healing; therefore it could be considered for quickening the episiotomy healing [64].

\section{Conclusion}

Considering aloe vera treatment for improvement of wound healing is useful as well as other standard treatments.

\section{Conflict of Interests}

The authors wish to confirm that there is no known conflict of interests associated with this paper and there has been no significant financial support for this work that could have influenced its outcome. 


\section{References}

[1] B. Pomahač, T. Svensjö, F. Yao, H. Brown, and E. Eriksson, "Tissue engineering of skin," Critical Reviews in Oral Biology and Medicine, vol. 9, no. 3, pp. 333-334, 1998.

[2] H. G. Bingham, D. Hudson, and J. Popp, "A retrospective review of the burn intensive care unit admissions for a year," Journal of Burn Care \& Rehabilitation, vol. 16, no. 1, pp. 56-58, 1995.

[3] V. McGill, A. Kowal-Vern, S. G. Fisher, S. Kahn, and R. L. Gamelli, "The impact of substance use on mortality and morbidity from thermal injury," Journal of Trauma: Injury, Infection \& Critical Care, vol. 38, no. 6, pp. 931-934, 1995.

[4] T. Blanks, S. Brown, B. Cosgruve et al., The Body Shop Book of Wellbeing Mind, Body, and Soul, Ebury Press, London, UK, 1998.

[5] Y. Iba, A. Shibata, M. Kato, and T. Masukawa, "Possible involvement of mast cells in collagen remodeling in the late phase of cutaneous wound healing in mice," International Immunopharmacology, vol. 4, no. 14, pp. 1873-1880, 2004.

[6] P. Martin, "Wound healing-aiming for perfect skin regeneration," Science, vol. 276, no. 5309, pp. 75-81, 1997.

[7] N. Ganapathy, S. S. Venkataraman, R. Daniel, R. J. Aravind, and V. B. Kumarakrishnan, "Molecular biology of wound healing," Journal of Pharmacy \& Bioallied Sciences, vol. 4, no. 6, supplement 2, pp. 334-337, 2012.

[8] J. O. Hollinger, C. E. Hart, S. N. Hirsch, S. Lynch, and G. E. Friedlaender, "Recombinant human platelet-derived growth factor: biology and clinical applications," The Journal of Bone and Joint Surgery-American Volume, vol. 90, no. 1, pp. 48-54, 2008.

[9] S. Barrientos, O. Stojadinovic, M. S. Golinko, H. Brem, and M. Tomic-Canic, "Growth factors and cytokines in wound healing," Wound Repair and Regeneration, vol. 16, no. 5, pp. 585601, 2008 .

[10] F. Chablais and A. Jaźwińska, "IGF signaling between blastema and wound epidermis is required for fin regeneration," Development, vol. 137, no. 6, pp. 871-879, 2010.

[11] S. Werner and R. Grose, "Regulation of wound healing by growth factors and cytokines," Physiological Reviews, vol. 83, no. 3, pp. 835-870, 2003.

[12] M. S. Bitar and Z. N. Labbad, "Transforming growth factor- $\beta$ and insulin-like growth factor-I in relation to diabetes-induced impairment of wound healing," Journal of Surgical Research, vol. 61, no. 1, pp. 113-119, 1996.

[13] M. H. Gartner, J. D. Benson, and M. D. Caldwell, "Insulin-like growth factors I and II expression in the healing wound," Journal of Surgical Research, vol. 52, no. 4, pp. 389-394, 1992.

[14] M. S. Bitar, "Insulin and glucocorticoid-dependent suppression of the IGF-I system in diabetic wounds," Surgery, vol. 127, no. 6, pp. 687-695, 2000.

[15] H. N. Antoniades, T. Galanopoulos, J. Neville-Golden, C. P. Kiritsy, and S. E. Lynch, "Expression of growth factor and receptor mRNAs in skin epithelial cells following acute cutaneous injury," The American Journal of Pathology, vol. 142, no. 4, pp. 1099-1110, 1993.

[16] Y. Chu, D. Yu, P. Wang, J. Xu, D. Li, and M. Ding, "Nanotechnology promotes the full-thickness diabetic wound healing effect of recombinant human epidermal growth factor in diabetic rats," Wound Repair and Regeneration, vol. 18, no. 5, pp. 499-505, 2010.
[17] R. Ghaderi, M. Afshar, H. Akhbarie, and M. J. Golalipour, "Comparison of the efficacy of honey and animal oil in accelerating healing of full thickness wound of mice skin," International Journal of Morphology, vol. 28, no. 1, pp. 193-198, 2010.

[18] R. Ghaderi and M. Afshar, "Topical application of honey for treatment of skin wound in mice," Iranian Journal of Medical Sciences, vol. 29, no. 4, pp. 185-188, 2004.

[19] R. Ghaderi and M. Afshar, "The effects of topical application octyl-2-cyanoacrylate tissue glue on treatment of skin wound in mice: an experimental study," Iranian Journal of Basic Medical Sciences, vol. 9, no. 2, pp. 136-143, 2006.

[20] R. Ghaderi, "Efficacy of epiglue, suture, honey and animal oil in accelerating healing of full thickness wound of skin in mice," Journal of Investigative Dermatology, vol. 125, supplement 1, p. A19, 2005.

[21] S. Y. Asadi, A. Zamiri, S. Ezzati, P. Parsaei, M. Rafieian, and H. Shirzad, "Effect of alcoholic extract of green tea (Camellia sinensis) on the healing process in surgical and burn wounds in rats," Journal of Birjand University of Medical Sciences, vol. 18, no. 1, pp. 1-9, 2011 (Persian).

[22] H. Golboe and R. Ghaderi, "Letter to editor: wound healing," Journal of Birjand University of Medical Sciences, vol. 19, no. 3, pp. 344-346, 2012 (Persian).

[23] R. P. Prado, S. B. Garcia, J. A. Thomazini, and C. E. Piccinato, "Effects of 830 and $670 \mathrm{~nm}$ laser on viability of random skin flap in rats," Photomedicine and Laser Surgery, vol. 30, no. 8, pp. 418-424, 2012.

[24] T. R. Dargaville, B. L. Farrugia, J. A. Broadbent, S. Pace, Z. Upton, and N. H. Voelcker, "Sensors and imaging for wound healing: a review," Biosensors and Bioelectronics, vol. 41, no. 1, pp. 30-42, 2013.

[25] N. Epstein, J. McGuinness, S. Persaud-Roberts et al., "How to reduce hospital-acquired pressure ulcers on a neuroscience unit with a skin and wound assessment team," Surgical Neurology International, vol. 3, no. 1, p. 138, 2012.

[26] F. E. Brölmann, D. T. Ubbink, E. A. Nelson, K. Munte, C. M. A. M. Van Der Horst, and H. Vermeulen, "Evidence-based decisions for local and systemic wound care," British Journal of Surgery, vol. 99, no. 9, pp. 1172-1183, 2012.

[27] M. D. Boudreau and F. A. Beland, "An evaluation of the biological and toxicological properties of Aloe barbadensis (Miller), Aloe vera," Journal of Environmental Science and Health, Part C: Environmental Carcinogenesis and Ecotoxicology Reviews, vol. 24, no. 1, pp. 103-154, 2006.

[28] B. O. Akinyele and A. C. Odiyi, "Comparative study of vegetative morphology and the existing taxonomic status of Aloe vera L.," Journal of Plant Sciences, vol. 2, no. 5, pp. 558-563, 2007.

[29] A. Barcroft, A. Myskja, and T. Reynolds, Aloe Vera: Nature's Silent Healer, BAAM, New York, NY, USA, 2003.

[30] T. Reynolds, Aloes: The Genus Aloe, CRC press, 2004.

[31] A. Surjushe, R. Vasani, and D. Saple, "Aloe vera: a short review," Indian Journal of Dermatology, vol. 53, no. 4, pp. 163-166, 2008.

[32] O. Rosca-Casian, M. Parvu, L. Vlase, and M. Tamas, "Antifungal activity of Aloe vera leaves," Fitoterapia, vol. 78, no. 3, pp. 219222, 2007.

[33] R. Henry, "An updated review of Aloe Vera," Cosmetics \& Toilertries, vol. 94, p. 42, 1979.

[34] R. L. Wynn, "Aloe vera gel: update for dentistry," General Dentistry, vol. 53, no. 1, pp. 6-9, 2005.

[35] L. Cole and C. Heard, "Skin permeation enhancement potential of Aloe Vera and a proposed mechanism of action based 
upon size exclusion and pull effect," International Journal of Pharmaceutics, vol. 333, no. 1-2, pp. 10-16, 2007.

[36] L. R. S. Moreira and E. X. F. Filho, "An overview of mannan structure and mannan-degrading enzyme systems," Applied Microbiology and Biotechnology, vol. 79, no. 2, pp. 165-178, 2008.

[37] K. Eshun and Q. He, "Aloe vera: a valuable ingredient for the food, pharmaceutical and cosmetic industries-a review," Critical Reviews in Food Science and Nutrition, vol. 44, no. 2, pp. 91-96, 2004.

[38] M. D. Boudreau and F. A. Beland, "An evaluation of the biological and toxicological properties of Aloe barbadensis (Miller), Aloe vera," Journal of Environmental Science and Health-Part C: Environmental Carcinogenesis and Ecotoxicology Reviews, vol. 24, no. 1, pp. 103-154, 2006.

[39] C. Muthu, M. Ayyanar, N. Raja, and S. Ignacimuthu, "Medicinal plants used by traditional healers in Kancheepuram District of Tamil Nadu, India," Journal of Ethnobiology and Ethnomedicine, vol. 2, article 43, 2006.

[40] K. Ashrafi, E. Esmaeli, N. Shahinfard et al., "The effect of hydroalcoholic extracts of Zizipus vulgaris L. on burn healing," Journal of Shahrekord University of Medical Sciences, vol. 12, no. 4, pp. 78-82, 2011.

[41] M. Rafieian, R. Ansari, R. Arami et al., "Effect of Teucrium polium and Boswellia serrata extracts on cotaneus burn wound healing in Balb/C mice," Journal of Shahrekord University of Medical Sciences, vol. 12, no. 1, pp. 49-53, 2011.

[42] L. Rafiee-Vardanjani, N. Sahinfard, M. Rahimi-Madiseh et al., "Effect of Portulaca oleracea L vice versa silver sulfadiazine on burn wound healing in Balb/c mice," Journal of Shahrekord University of Medical Sciences, vol. 13, no. 6, pp. 92-100, 2012.

[43] A. Atiba, H. Ueno, and Y. Uzuka, "The effect of aloe vera oral administration on cutaneous wound healing in type 2 diabetic rats," Journal of Veterinary Medical Science, vol. 73, no. 5, pp. 583-589, 2011.

[44] M. C. Robson, T. J. Krizech, and J. P. Heggers, "Biology of surgical infection," in Current Problems in Surgery, M. Ravich, Ed., pp. 121-127, Year Book Medical, Chicago, Ill, USA, 1st edition, 1973.

[45] W. K. Stadelmann, A. G. Digenis, and G. R. Tobin, "Impediments to wound healing," American Journal of Surgery, vol. 176, no. 2, supplement, pp. 39S-47S, 1998.

[46] D. G. Greenhalgh, "The role of apoptosis in wound healing," International Journal of Biochemistry and Cell Biology, vol. 30, no. 9, pp. 1019-1030, 1998.

[47] Y. Shi and J. Massagué, "Mechanisms of TGF- $\beta$ signaling from cell membrane to the nucleus," Cell, vol. 113, no. 6, pp. 685-700, 2003.

[48] P. R. Roberts, K. W. Black, J. T. Santamauro, and G. P. Zaloga, "Dietary peptides improve wound healing following surgery," Nutrition, vol. 14, no. 3, pp. 266-269, 1998.

[49] J. Massagué, “The transforming growth factor-beta family," Annual Review of Cell Biology, vol. 6, no. 1, pp. 597-641, 1990.

[50] A. E. Postlethwaite, J. Keski-Oja, H. L. Moses, and A. H. Kang, "Stimulation of the chemotactic migration of human fibroblasts by transforming growth factor $\beta$," The Journal of Experimental Medicine, vol. 165, no. 1, pp. 251-256, 1987.

[51] L. Pertovaara, A. Kaipainen, T. Mustonen et al., "Vascular endothelial growth factor is induced in response to transforming growth factor- $\beta$ in fibroblastic and epithelial cells," The Journal of Biological Chemistry, vol. 269, no. 9, pp. 6271-6274, 1994.
[52] T. Sánchez-Elsner, L. M. Botella, B. Velasco, A. Corbí, L. Attisano, and C. Bernabéu, "Synergistic cooperation between hypoxia and transforming growth factor- $\beta$ pathways on human vascular endothelial growth factor gene expression," Journal of Biological Chemistry, vol. 276, no. 42, pp. 38527-38535, 2001.

[53] Q. H. Song, V. E. Klepeis, M. A. Nugent, and V. TrinkausRandall, "TGF- $\beta 1$ regulates TGF- $\beta 1$ and FGF- 2 mRNA expression during fibroblast wound healing," Journal of Clinical Pathology: Molecular Pathology, vol. 55, no. 3, pp. 164-176, 2002.

[54] E.-J. Moon, Y. M. Lee, O.-H. Lee et al., "A novel angiogenic factor derived from Aloe vera gel: $\beta$-sitosterol, a plant sterol," Angiogenesis, vol. 3, no. 2, pp. 117-123, 1999.

[55] C. Liu, M. Y. K. Leung, J. C. M. Koon et al., "Macrophage activation by polysaccharide biological response modifier isolated from Aloe vera L. var. chinensis (Haw.) Berg.", International Immunopharmacology, vol. 6, no. 11, pp. 1634-1641, 2006.

[56] A. Oryan, A. T. Naeini, B. Nikahval, and E. Gorjlan, "Effect of aqueous extract of Aloe vera on experimental cutaneous wound healing in rat," Veterinarski Arhiv, vol. 80, no. 4, pp. 509-522, 2010.

[57] Y. Jia, G. Zhao, and J. Jia, "Preliminary evaluation: the effects of Aloe ferox Miller and Aloe arborescens Miller on wound healing," Journal of Ethnopharmacology, vol. 120, no. 2, pp. 181-189, 2008.

[58] M. Kashanian, M. M. Lakeh, A. Ghasemi, and S. Noori, "Evaluation of the effect of vitamin $\mathrm{E}$ on pelvic pain reduction in women suffering from primary dysmenorrhea," Journal of Reproductive Medicine, vol. 58, no. 1-2, pp. 34-38, 2013.

[59] J. Somboonwong, S. Thanamittramanee, A. Jariyapongskul, and S. Patumraj, "Therapeutic effects of aloe vera on cutaneous microcirculation and wound healing in second degree burn model in rats," Journal of the Medical Association of Thailand, vol. 83, no. 4, pp. 417-425, 2000.

[60] V. Hajhashemi, A. Ghannadi, and A. H. Heidari, "Anti-inflammatory and wound healing activities of Aloe littoralis in rats," Research in Pharmaceutical Sciences, vol. 7, no. 2, pp. 73-78, 2012.

[61] M. Daburkar, V. Lohar, A. Rathore, P. Bhutada, and S. Tangadpaliwar, "An in vivo and in vitro investigation of the effect of Aloe vera gel ethanolic extract using animal model with diabetic foot ulcer," Journal of Pharmacy and Bioallied Sciences, vol. 6, no. 3, pp. 205-212, 2014.

[62] M. R. Akhoondinasab, M. Akhoondinasab, and M. Saberi, "Comparison of healing effect of aloe vera extract and silver sulfadiazine in burn injuries in experimental rat model," World Journal of Plastic Surgery, vol. 3, no. 1, pp. 29-34, 2014.

[63] A. Oryan, A. Mohammadalipour, A. Moshiri, and M. R. Tabandeh, "Topical application of Aloe Vera accelerated wound healing, modeling and remodeling: an experimental study with significant clinical value," Annals of Plastic Surgery, 2015.

[64] F. Eghdampour, F. Jahdie, M. Kheyrkhah, M. Taghizadeh, S. Naghizadeh, and H. Hagani, "The impact of Aloe vera and calendula on perineal healing after episiotomy in primiparous women: a randomized clinical trial," Journal of Caring Sciences, vol. 2, no. 4, pp. 279-286, 2013. 


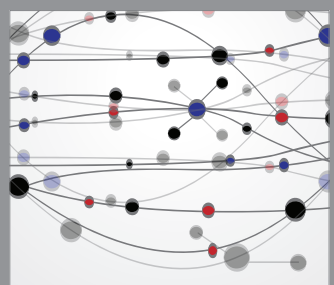

The Scientific World Journal
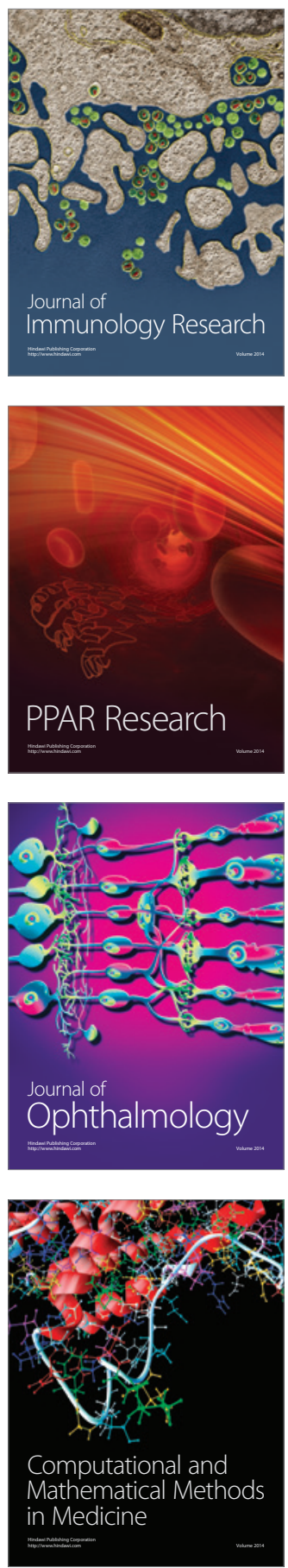

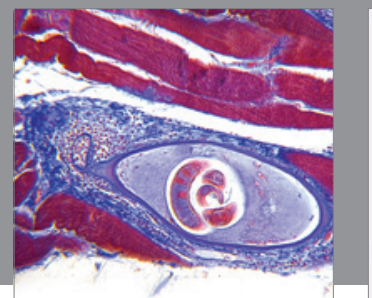

Gastroenterology

Research and Practice
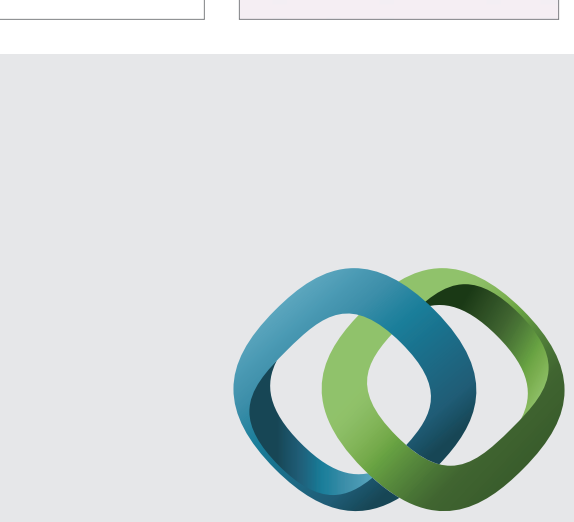

\section{Hindawi}

Submit your manuscripts at

http://www.hindawi.com
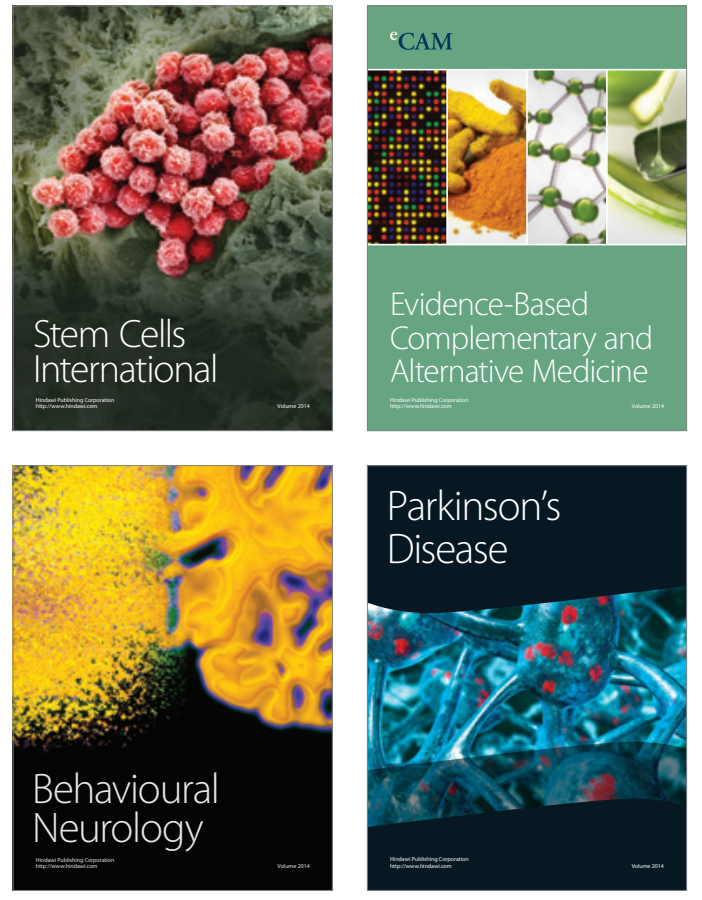
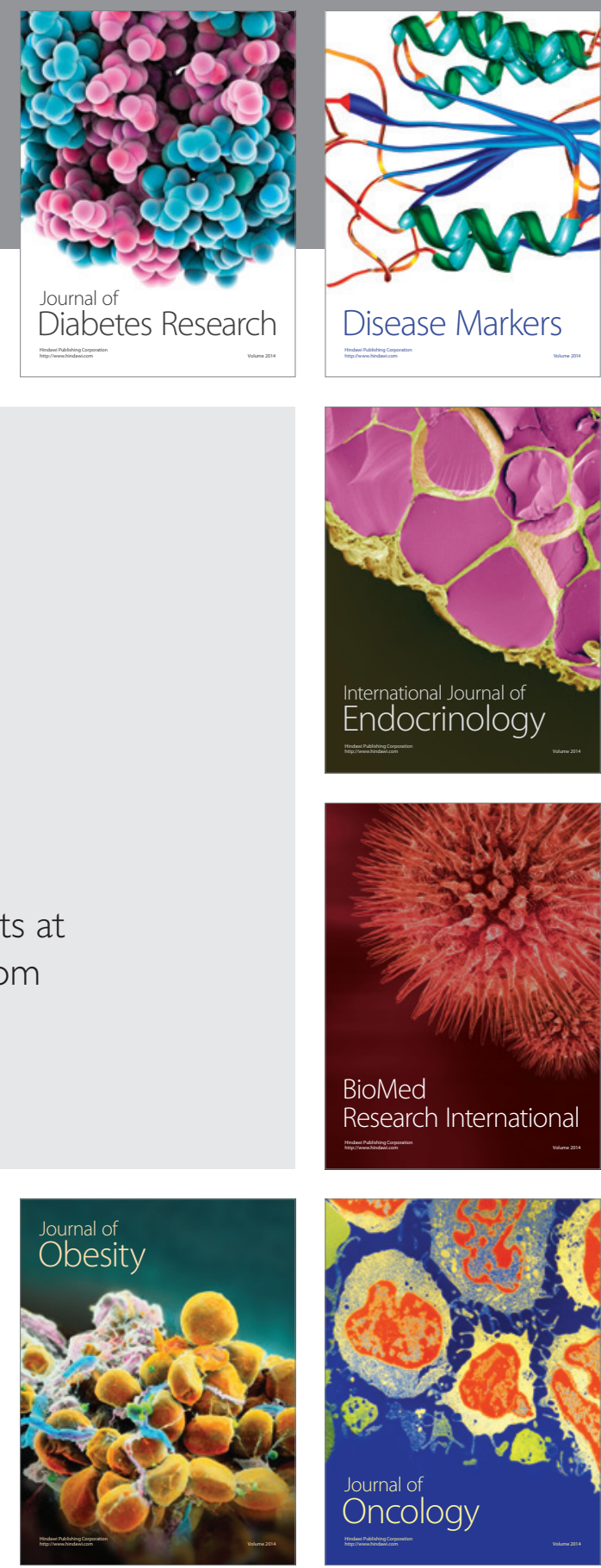

Disease Markers
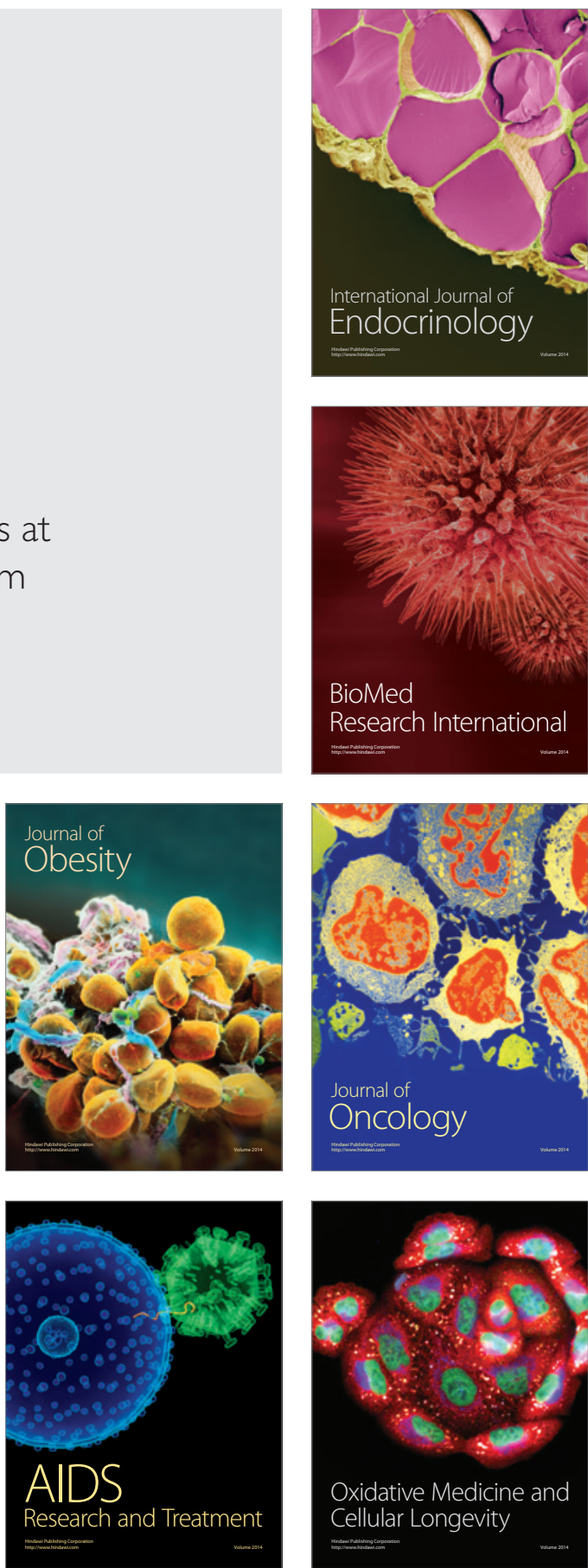